ARTICLE

Check for updates

https://doi.org/10.1057/s41599-020-0440-5

\title{
Dissemination of international rankings: characteristics of the media coverage of the Shanghai Ranking in the French press
}

\author{
Christine Barats $^{1 凶}$
}

\begin{abstract}
The number of university rankings proliferated in the 2000 s against a background of reforms in higher education (HE) and the development of a discourse on academic 'excellence'. The analysis of the emergence and treatment in the French press of the so-called 'Shanghai ranking', the first international ranking to originate in the world of academia, makes it possible to objectify the characteristics of its dissemination in France from June 2003 when it was first published in China. Although there was no intention initially to have this ranking circulated in France, it ultimately became more widely known owing to its status as a useful resource for different actors working against a background of HE reforms in France. This article discusses the intensification of media coverage from 2007 onwards, as well as the role played by certain media organisations and players (analysis of French press corpus and interviews). It highlights the importance of depreciative framing for French universities to 'create a buzz' along with the co-construction of the process by different players. The ranking has become a journalistic resource, as well as a political argument for reforms and a communication tool for certain university presidents.
\end{abstract}

\footnotetext{
${ }^{1}$ Céditec Université Paris Est et Université de Paris, Paris, France. ${ }^{凶}$ email: christine.barats@parisdescartes.fr
} 


\section{Introduction}

nternational academic rankings have proliferated since the 2000s in a context marked, especially in France, by reforms in higher education \& research (HE\&R) (Musselin, 2009, 2017; Ravinet, 2011). While research on rankings has chiefly focused on the methodologies (Eloire, 2010; Vught and Westerheijden Don, 2010; Docampo, 2013; Docampo et al., 2015; Werron and Ringel, 2017) or their impacts (Espeland and Sauder, 2007; Hazelkorn, 2007, 2011, 2014, 2015; Brankovic et al., 2018), less work has been carried out on the conditions governing the dissemination of, and the debate about, academic rankings.

The Academic Ranking of World Universities (ARWU), better known under the name of 'Shanghai Ranking', is the first international ranking to originate in the world of academia. This ranking of the world's 'top' 500 universities was drawn up by four researchers from Shanghai Jiao Tong University who published it on their university's website in June 2003. The designers of this ranking began by conducting a benchmarking exercise on existing league tables and types of indicators selected from 1999 to 2001. They designed and produced this ranking with limited resources using databases accessible online. The ranking criteria are based on the number of Nobel laureates and Fields medallists ${ }^{1}$ in addition to bibliometric data, notably the number of citations in the journals Nature and Science (Liu and Cheng, 2005). Two thousand educational and research institutions were included in the review out of the seventeen thousand institutions listed worldwide; the designers of Academic Ranking of World Universities chose these institutions because they satisfied the ranking criteria (Nobel Prize winners, Fields medallists, publications in certain journals, etc.) (Liu and Cheng, 2005, p. 2) (Fig 1).

Since 2009, the ranking has been compiled by Shanghai Ranking Consultancy, an educational consulting firm working independently of the university with a staff of about 30, three of whom are in charge of updating the ranking, a sign of the team's greater professionalism and the depth of interest generated by the rankings. Initially, the researchers responded to a domestic Chinese demand related to the reforms of higher education in China carried out in the 1990s (Charroin, 2015; Soulas, 2016). The aim of this ranking was to help the Chinese compare their universities with their international counterparts (Liu and Cheng, 2005; Billaut et al., 2010) and this information prepared for a domestic audience was not intended to be circulated outside of China. Accordingly, no communication or press service contributed to its media coverage. The ranking did, however, spread through various channels, notably in France ${ }^{3}$ (via the European Commission's Cordis website, various symposia, the press, etc.), and has been referred to in a large number of publications as the archetype of academic rankings that, ultimately, resulted in a non-desired yet successful communications campaign for Jiao Tong University.

In France, the interest given to the Shanghai ranking invites to examine the modalities of its circulation and focus attention on the specifics of its dissemination. Indeed, this ranking has occupied-and still occupies-an atypical place in France compared with other rival academic rankings, such as the World University Rankings published by The Times in the Times Higher Education Supplement (THES) since 2004 (Barats, 2018). This interest is also anomalous if the frequency and volume of publications devoted to this classification in France is compared with the lack of coverage received in the United States. The Shanghai ranking has produced little reaction in the USA dominated by a tradition of national rankings, despite the fact that North American universities have ranked high in the Shanghai league table since it was first compiled. Harvard University, for example, has been ranked No.1 for the past fifteen years but has made no comment about the regularity of this performance ${ }^{4}$.

To explain this situation, I have developed and tested a number of hypotheses: firstly, that this ranking, which was not initially intended for press coverage, ultimately attracted the media's attention in France because its co-development by a variety of different actors revealed the plurality of concurrent rationales, secondly, that the development of this process (i.e., the time when the ranking was covered by the press and by which newspapers) illuminates the different logics of media coverage in France; and, thirdly, that the profiles and discourses developed by the different actors reflect the arguments and power relationships existing at the very heart of the media coverage process.

In order to understand the distinctive features of the dissemination of the Shanghai rankings in France, I examined how these league tables have been covered in the print media since 2003, considering the news media as places dedicated to the

\section{A Criteria and Weights of ARWU}

\begin{tabular}{|c|l|c|c|}
\hline Criteria & \multicolumn{1}{|c|}{ Indicator } & Code & Weight \\
\hline $\begin{array}{c}\text { Quality of } \\
\text { Education }\end{array}$ & $\begin{array}{l}\text { Alumni of an institution winning Nobel Prizes } \\
\text { and Fields Medals }\end{array}$ & Alumni & $10 \%$ \\
\hline \multirow{2}{*}{$\begin{array}{c}\text { Quality of } \\
\text { Faculty }\end{array}$} & $\begin{array}{l}\text { Staff of an institution winning Nobel Prizes and } \\
\text { Fields Medals }\end{array}$ & \begin{tabular}{l} 
Award \\
\cline { 2 - 4 }
\end{tabular} & $20 \%$ \\
\hline \multirow{2}{*}{$\begin{array}{c}\text { Research } \\
\text { Output }\end{array}$} & Papers publed researchers in 21 broad subject & $\mathrm{HiCi}$ & $20 \%$ \\
\cline { 2 - 4 } & $\begin{array}{l}\text { Papers indexed in Science Citation Index- } \\
\text { expanded and Social Science Citation Index }\end{array}$ & PUB & $20 \%$ \\
\hline $\begin{array}{c}\text { Per Capita } \\
\text { Performance }\end{array}$ & $\begin{array}{l}\text { Per capita academic performance of an } \\
\text { institution }\end{array}$ & $P C P$ & $10 \%$ \\
\hline
\end{tabular}

*: For institutions specialized in humanities and social sciences such as London School of Economics, N\&S is not considered and the weight of N\&S is relocated to other indicators 
production and dissemination of discourse (Miège, 2010) but also as spaces of expression, leading to the emergence and coconstruction of debates or events (Champagne, 1991, 2000) through which, and for which, different players play out a network of power relationships (Foucault, 1971). In this way, the mainstream and specialised print media are players in debates on higher education \& research (Fridenson, 2010, p. 53) because they are read by stakeholders in academia and offer them forums for their expression. In pursuit of these different hypotheses, I set out to identify which press agencies and newspapers contributed to the dissemination of the Shanghai rankings. To do so, different newspaper databases have been consulted in order to retrieve all the articles, interviews and opinion pieces dealing with the ranking. Attention has been focused on the panoply of media motivations and on the players' different strategies as expressed in their discourses in order to reveal the plurality of rationales involved in the media coverage process and, more particularly, their link with the debates on higher education \& research. The analysis of the discourses and interviews enabled to highlight the plurality of the different concurrent rationales: the rankings as a journalistic resource making it possible to create a 'buzz' and attract attention; the rankings as a judgement tool capable of shaping the prestige enjoyed by higher education institutions; the rankings as a political argument for reforms and a communication tool for certain university presidents. Given the scope of these issues, the criteria chosen to constitute the documentary corpus have not favoured any predetermined type of print media outlet, thereby enabling us to list all statements related to the rankings and to identify the newspapers and news agencies at the forefront of this media coverage. Several databases have been searched to be sure to analyse all the articles, interviews, opinions diffused over the period (Factiva, Europress, the archives of Le Monde, Libération and AEF, a press agency specialising in education) using full-text searches with different terms (in French): 'classement mondial' (world ranking), 'classement international' (international ranking) and 'classement de Shanghai' (Shanghai ranking), and using different spellings for 'Shanghai' ('Shanghai', 'Shangai', 'Shanghai'). AEF5', a French press agency specialising in education, as well as AFP, Agence France Presse, the generalist French press agency have been selected because AEF is a key source of information for people involved in higher education \& research, notably higher education managerial staff (establishment directors, training managers, academic component directors, etc.). It is also a semi-official source for the media. The hypothesis needed to identify press agencies and newspapers to analyse the panoply of media motivations.

The press corpus tends towards exhaustiveness, representing more than one million hits, 119 different print media outlets, and 1520 documents, including 90 opinion pieces from June 2003 to September 2014. Textual statistics tools have been used for a systematic corpus analysis and observe discursive characteristics. As the use of textual statistics tools implies that the documentary corpus is closed, monitoring work since 2014 has been carried out to complete the corpus, using online notifications and systematic collection of references to the ranking when the results are published each year on 15 August (national or regional daily press, magazines) ${ }^{6}$. The analysis of the press corpus (press and press agencies) has been combined with the analysis of interviews with journalists and individuals active in higher education \& research to be able to understand what the journalists' sources were and what goals they were pursuing in their articles. Interviews of individuals active in higher education \& research were also precious to understand the wider context of the media coverage process.

The press corpus provides access to a variety of data relating to: the type of media outlets, the deployment and intensity of media coverage over time, the profile of the individuals cited or of those who expressed themselves in opinion pieces and the discursive characteristics of the statements. The qualitative interviews ${ }^{7}$, on the other hand, enabled to verify certain hypotheses related to the reasons for this media coverage. The longitudinal and monographic perspective adopted allowed to objectify the media coverage process and, in particular, to focus attention on the role of the media outlets and the profiles of the players who have referred to the rankings without, however, viewing this process as linear and continuous but, on the contrary, driven by multiple colliding or intermingling rationales. This is why I have adopted the notion of 'co-construction' to capture the rationales and power relationships exercised in and through discourses delivered during the media coverage process. The notion of co-construction makes it possible to avoid an over-interpretation of the different media approaches: in this case, a form of media-centricity potentially induced by the use of a corpus of news publications.

In order to examine the different actors in this co-development process and test the hypotheses, I will start by focusing on the specifics of its dissemination in the press from 2003 to 2014 before examining the profiles of the different players who have referred to this ranking in order, ultimately, to highlight the socio-discursive practices to which it has given rise.

\section{A derogatory framing and two-step media coverage process: the critical juncture of $\mathbf{2 0 0 7}$}

Seven months were to elapse between the publication of the ranking in China in June 2003 and the first reference to these league tables in the French media. The study of the data derived from the documentary corpus and, in particular, an analysis of the temporal distribution of references show that the media coverage process occurred in two stages. In an initial phase, running from December 2003 to May 2007, the media coverage was confidential, i.e., limited to a small circle of newspapers and players who presented the ranking in a negative light questioning the positions accorded to leading French academic institutions, thereby using the ranking as a resource to create a 'buzz' and attract attention: a subject reported in the press because of the derogatory framing (i.e., a depreciative framework for French universities).

Then, in a second phase, the media coverage intensified in terms of both volume and the diversification of media outlets.

It was AEF, the press agency specialising in education, and the national daily newspapers-notably Les Echos ${ }^{8}$ daily but also Libération, Le Figaro and La Tribune-which relayed the information at the beginning of the process ${ }^{9}$. AEF covered the Shanghai ranking in a press review published in December 2003 (taken from The Australian newspaper) and, subsequently, in the form of a news bulletin published in January 2004. The interview with the journalist who wrote this bulletin ${ }^{10}$ revealed the role played by indirect sources of information-in this case a newsletter to which the journalist was subscribed published by Paris Diderot University (also known as the University of Paris VII), which caught her attention on 9 January 2004-and not the extract from the Australian newspaper.

Journalist interview, AEF, 29 March 2011: 'I was the first in France to talk about it. I came across it in an academic newsletter-La lettre de Jean Grisel-published by Paris Diderot University, which included a brief reference to this ranking. I was surprised that it came from China. At that time, we tended to look down on Chinese universities'.

AEF journalists have subsequently dealt with the ranking on a regular basis and enjoy a leading position in the media coverage process (Fig. 2). In comparison, the mainstream media paid little 


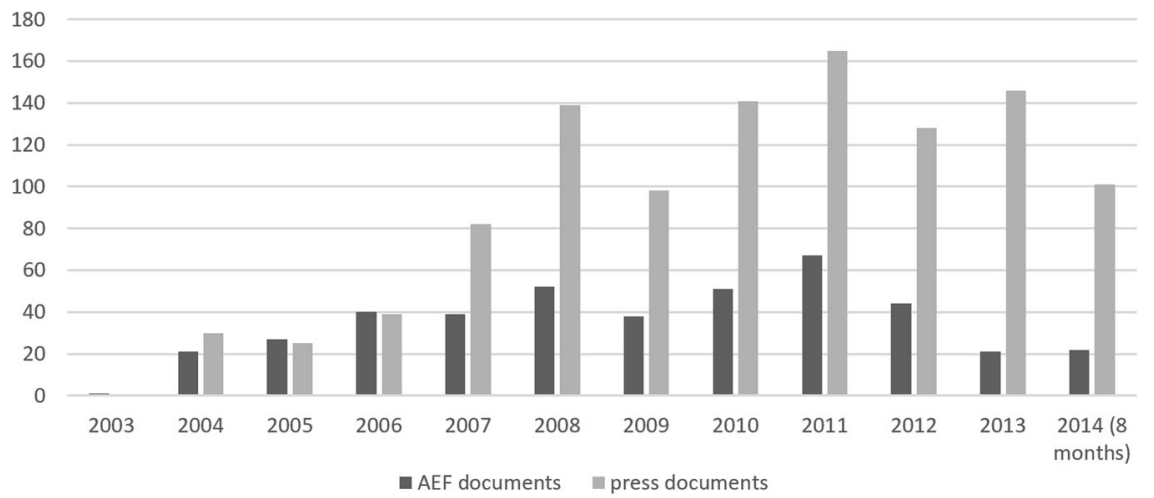

Fig. 2 Annual distribution of media coverage. AEF documents, the press agency specialising in education (number of bulletins and interviews per year) and the press corpus (number of articles, interviews, opinion pieces per year), 2003-2014.

attention to the ranking until 2006, with 2007 marking a turning point in the media coverage process, especially for the nonspecialised press (as opposed to the economic and financial press).

Over the period studied, $86 \%$ of the corpus was created post2006. This result highlights the role played by AEF, the press agency specialising in education and Les Echos at the beginning of the process. In the case of AEF, it represents an indicator of the interest expressed by different HE actors, in France and more widely in Europe, in the rankings as shown by a survey of university presidents worldwide conducted in 2006 by Hazelkorn (2007). The role of Les Echos, a daily economic newspaper, confirms the affinity between this tool and the economic domain, where league tables are frequent.

Starting in May 2007, the media coverage process grew in intensity, characterised by diversification of the media outlets. The regional daily press and magazines as varied as Le Point, l'Express, Marianne, 01 informatique or l'Usine Nouvelle all covered the academic ranking against a background of reforms and disputes in higher education \& research (demonstrations, calls for strike action, etc.). The growing number of media outlets covering the university ranking, as well as the diversity of these news organisations starting in 2007, emphasises the importance of the socio-political context, notably the mobilisation that followed the adoption of the so-called LRU Law ${ }^{11}$ (LRU for Libertés et responsabilités des universities, or 'Freedom and Responsibilities of the Universities' Act), promulgated in August of that year.

Starting in 2008 and up until 2012, Le Monde was the daily newspaper that most frequently addressed the university ranking (in opinion pieces, interviews, articles) and competed with the place occupied by Les Echos at the beginning of the process. Unlike Les Echos, Le Monde made no contribution to the media coverage at the beginning of the process and, as in the case of $L a$ Croix, its articles focused on the methodological limits of these league tables and qualified their true impact. The positioning of the media outlets-in this case, their close relationships with individuals active in the academic and political communities-as well as their status as competitors explain the interruptions in their coverage of the rankings, and the specific characteristics of this coverage. For example, Le Monde, which enjoys close ties with the academic community, distinguished itself from Les Echos by only addressing the ranking through opinion pieces starting in 2006, before beginning to publish the results as of 2007. Routine professional behaviour, notably journalists' reading of bulletins published by AFP (Agence France Presse) and their consultation of rival newspapers, would drive the diversification of news organisations interested in the league tables from 2007 onwards, leading to an intensification of media coverage.
Interviews with journalists reveal that they anticipated the publication of the annual ranking results (news monitoring activities and instructions given in the event of the journalists' absence). Various factors helped to give routine status to the coverage of the Shanghai ranking: the regularity of the publication date (usually 15 August, except in 2009), the impact of circulation between media outlets, the shortage of newsworthy events in the summer months, as well as the way the results were framed by the media. The monitoring work we have carried out since September 2014 both complements and confirms these findings. The academic ranking is now the subject of regular reporting in the press. The announcement of the results in August 2015, 2016, 2017 and 2018 triggered extensive coverage in the French national and regional daily press and confirmed their front-page newsworthiness. To illustrate this, we could quote the headlines of Les Echos, which confirm the importance given by this daily newspaper to the ranking: 16 August 2016, Palmarès des universités: les raisons du déclin français ('University rankings: the reasons for the French decline'); 16 August, 2017, Universités: pourquoi la France cède du terrain ('Universities: why France is losing ground') and 15 August, 2018, Universités: La France résiste dans le classement de Shanghai ('Universities: France is holding its own in the Shanghai ranking').

It should be noted that the legitimacy and scientific value accorded to the quantified data, as well as the plasticity of the ranking format chosen to satisfy the illustration-related constraints required by the production of data, encouraged the media to cover the ranking, in this case as a journalistic resource for creating an 'event' (Champagne, 1991). As such, the rankings viewed as a simplification technology (Espeland, 2015, p. 29), based on the listing technique as a spatial distribution of information (Goody, 1999), constitutes a semio-cognitive condition favourable to its coverage, notably in the media.

These initial results on the characteristics of the media coverage have been supplemented by an analysis of the discursive dimension of its treatment, notably by an analysis of the ways in which the event was framed. The analysis of the framing of the event (Goffman, 1991) is understood in this article as the way in which the event is constructed and how some aspects of it are emphasised at the expense of others. In order to reveal the salient discursive features, we used textual statistical tools (TextObserver $^{12}$ and Alceste $\left.{ }^{13}\right)$ to identify the terms most frequently used in the press corpus (more than one million hits from 2003 to 2014). The textual statistical analysis of the corpus revealed the importance of derogatory framing, i.e., the emphasis placed on what is presented as the underachievement on the part of French institutions with the use of terms such as traine or retard, both expressing the idea of 'falling or lagging behind'. The first articles 
devoted to the ranking in 2004 focus on what were considered the 'bad' academic results of French institutions, with a preference for metaphors such as choc ('shock' or 'trauma') or électrochoc ('electroshock'). As shown in the examples below, the newsworthiness (or 'buzz') is created by the angle given to the presentation of the poor academic performance of French institutions. ${ }^{14}$

Les Echos, 15/11/2004: 'France lags behind in the new world ranking.

Shanghai's Jiao Tong University recently completed its second world ranking: France only comes in a No.41'.

AFP, 29/09/2005: '[...] The highly feared 'Shanghai ranking' gives France a very poor score every year: the top French university is ranked 46th in 2005'.

Les Echos, 01/04/2006: 'What are our universities still worth?

[...] Underfunded, overcrowded, fragmented, French campuses pale into insignificance on the international scene: the top university only comes in 46th position in the now celebrated 'Shanghai ranking' and the top grande école... in 93rd position. This ranking, designed by a university (Jiao Tong) hitherto unknown in the world of academia and now enjoying the status of an international benchmark, came as quite a shock. This speaks volumes about the French decline'.

Le Figaro, 27/02/2008: 'Universities: a world ranking shows how far the French have fallen behind

Higher education: The Shanghai ranking of universities per discipline relegates French institutions to a position of mediocrity.

The 2008 edition of the famous ranking of world universities published by Shanghai Jiao Tong university, scrutinised by academics around the world, was recently published per major discipline (medicine, mathematics, computer science, social sciences and earth sciences). [...] The 2008 ranking is as mediocre as last year's: only one French university is included in the Top 100 medical schools'.

Le Monde, 03/05/2012: '[...] When, in 2003, the 'Shanghai shock' challenged the assumptions of French higher education, the right deemed it necessary to look at what had proved successful elsewhere and to draw inspiration from it to avoid demotion'.

\section{Les Echos, 26/08/2013: The message from Shanghai}

It's a somewhat humiliating ordeal but we've got used to it! As has been the case every year since 2003, the worldwide ranking of universities, known as the 'Shanghai ranking', confirms France's mediocre position: only 20 of our institutions of higher education are in the top 500-placing us well behind the United States, China, Germany and the United Kingdom-and just 4 in the top 100. French academia takes solace by challenging the appraisal method; their arguments are valid but they miss the essential point'.

While the vocabulary used (quotations above) confirms the emphasis on underperformance ('poor score', 'mediocre'), the syntactical structures reinforce this framework with the use of the adverb phrase ne... que ('only') or the repeated presence of the adjective seul(es) ('alone') or the adverb seulement ('only') to express the notion of restriction.

Interviews with journalists highlighted that the simplicity of the ranking criteria-chiefly bibliometric data (taken from the Science Citation Index (SCI) and Arts \& Humanities Citation Index databases), as well as success in obtaining awards enjoying strong international recognition such as the Nobel Prize or Fields medal -were considered a guarantee of recognition and credibility. If the performance of French institutions, qualified as 'poor' became a journalistic resource to create an event, the No.1 position enjoyed by Harvard University was considered to be axiologically consistent with representations of academic prestige and reinforced the legitimacy given to the results of the ranking.

It should be noted that the desire to create a 'buzz' (i.e., create an event and increase media attention), linked to the framing of the results in terms of underperformance, confirms the results of other studies, such as those conducted by Frédéric Pierru on the media coverage of hospital rankings (Pierru, 2004) or those conducted by Xavier Pons on the OECD PISA survey (Pons, 2015), underlining the importance of the derogatory framing in how the event is construed, as well as the seriousness of debates and reforms in the areas concerned. The use of the ranking by political players, notably in 2007, would amplify this process, as would the reactions and behaviours of members of the academic community.

\section{Ranking as an argument for political players to justify reforms and as a communication tool for certain institutions} The systematic survey in the corpus of stakeholders cited or who expressed themselves in the case of interviews or published opinion pieces indicates that a wide range of different players have made use of the ranking. An analysis of their profiles ${ }^{15}$ reflects their specific characteristics: they are mainly representatives of a political nature, notably the regulatory authorities, university presidents, heads of grandes écoles ${ }^{16}$ or research bodies (public research organisations such as the CNRS (Centre National de la Recherche Scientifique $\left.{ }^{17}\right)$ ). In France, higher education and scientific research is characterised by the coexistence of three systems: universities, public institutions that have an open admissions policy, a non-university sector, grandes écoles, which have a highly selective admissions policy and scientific research bodies like CNRS, not taken into account by Academic Ranking of World Universities (ARWU) because of their status as research bodies $^{18}$. ARWU's criteria are not favourable to the French system: the grandes écoles are widely regarded as prestigious, as well as the CNRS, both have produced most of the scientists and executives in France, but the Shanghai ranking neutralises French representations of academic prestige. This constitutes a political opportunity to justify reforms. This background of the French system helps to explain the specific characteristics of actors reacting to the ranking.

The analysis of the profiles of individuals who expressed themselves reveals that the intensification of media coverage in 2007 is linked to the frequency of its use by Nicolas Sarkozy, President of the Republic, and by Valérie Pécresse, Minister of Higher Education \& Research (2007-2011) to the effect that the ranking was used as a political argument to justify reform. Although not explicitly mentioned in the letter of appointment addressed to Valérie Pécresse, improving the position of our higher education institutions in the international rankings' was one of the objectives set for the Minister by the President of the Republic ${ }^{19}$.

Nicolas Sarkozy regularly refers to the academic ranking, which he uses in his speeches as an argument justifying reforms, taking a name and shame approach. 


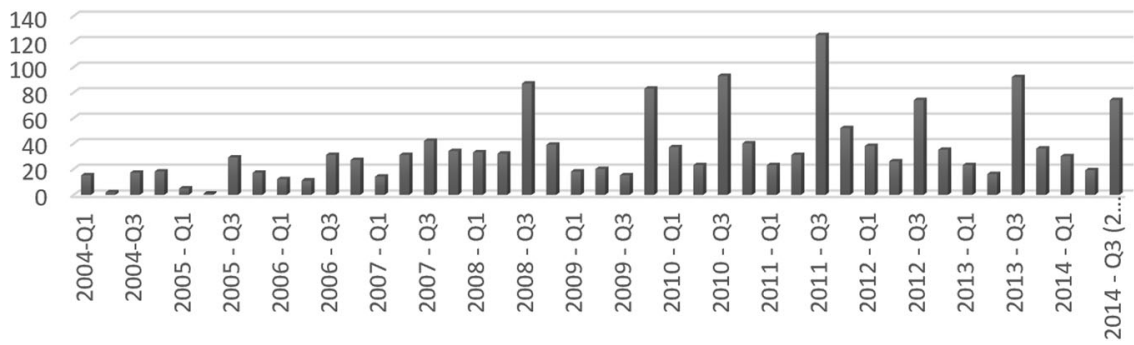

Fig. 3 Quarter distribution of media coverage. Number of documents per quarter (press corpus and AEF corpus, the press agency specialising in education).

Nicolas Sarkozy, excerpt from the speech delivered on 28/ $01 / 2008$ during a ceremony in honour of Albert Fert, quoted in Les Echos, 30/01/2008: 'Nicolas Sarkozy's hardpunching speech on research triggered strong reactions yesterday. On Monday, in Orsay, the President of the Republic outlined the avenues for a major reform of this '50-year-old system that penalises us'. Drawing up a depressing diagnosis of the 'difficulties' facing French research at the international level (in terms of publications, the Shanghai ranking, brain drain, etc.), he undertook to increase research funding to $3 \%$ of GDP by 2012 . But he also warned: 'This massive effort will go hand-in-hand with reform'.

With regard to statements published by her ministry, Valérie Pécresse refers to the ranking in two main contexts: to pursue projects aimed at the merger of universities with a view to improving their ranking and also to promote the production of a European ranking system, to compete with the Shanghai ranking.

Interview published in Le Figaro, 27/02/2008, Valérie Pécresse, Minister of Higher Education \& Research: 'The problem with the Shanghai ranking is its very existence. It cannot be ignored because students all over the world refer to it. France must enter this global battle of knowledge, even if we preserve certain specificities of the French system, notably the low admission fees. But we must also establish our own ranking at a European level'.

Le Figaro, 02/07/2008, Valérie Pécresse, Minister of Higher Education \& Research: 'Competing with the now very famous 'Shanghai ranking', in which, year after year, French universities occupy a mediocre position: this is the objective stated yesterday by Valérie Pécresse. The Minister for Higher Education wants to take advantage of the French Presidency of the European Union to draw up a European ranking system'.

Valérie Pécresse quoted in Les Echos, 26/06/2008: 'The first meeting of the board of directors of PRES recently validated a symbolic decision by welcoming in its midst Jean-Monnet University and the Saint-Étienne School of Mining. In addition to a single signature under the name 'Université de Lyon' to identify the second-largest French scientific hub when awarding doctorates or attributing scientific publications, 'this hub will enjoy greater prestige while the university of Lyon does not currently appear in the Shanghai ranking', noted the Minister of Higher Education, Valérie Pécresse?.

If the ranking is a central political argument to justify university mergers, it would also allow the Minister to argue for the production of a European ranking system, supposed to compete with the Chinese ranking ${ }^{20}$. She would promote this initiative at the European level during the French Presidency of the EU Council. The discursive uses of the ranking lie at the heart of the communications released by the President and Minister and confirm the symbolic and argumentative dimension of this ranking, a tool for justifying and legitimising the projects drawn up for higher education \& research during N. Sarkozy's presidency. The two peaks of media coverage noted in 2008 and 2011 (Fig. 2) correspond to periods of contestation and reform in higher education \& research. As such, the use of the ranking as a political argument contributes to the co-construction of its media coverage outside the periods when the results are announced. Figure 3 illustrates the coverage peaks in August at the time of the announcement of the results (third quarter, or Q3) and also shows that it was used outside this period.

In 2011, Valérie Pécresse, Minister of Higher Education, frequently refers to the ranking when she launched the first call for 'excellence initiative projects' (projets d'initiative d'excellence financed with the framework of the 'Investment Programme for the Future' PIA ${ }^{21}$ ), which fuelled debates on higher education \& research ${ }^{22}$. The 2011 peak can also be explained by the visit to France in July 2011 of the designers of the Chinese ranking. This context proved favourable for the diversification of the media outlets that dealt with the ranking at the moment the results were published.

Every year, the publication of the results is announced in a press release by the Minister of Higher Education \& Research. It should be noted that in May 2017, a report from the General Inspectorate of National Education and General Inspectorate of the Administration of National Education \& Research (Inspection générale de l'éducation nationale, or IGEN, and Inspection générale de l'administration de l'éducation nationale et de la recherche, or IGAENR) on international rankings ${ }^{23}$ was sent to the Minister of Higher Education \& Research and the Minister of the Economy, indicating continued interest in academic rankings and, in particular, in the Shanghai ranking. In February 2019, the Minister of Higher Education, Frédérique Vidal, sent a letter to the President of the National Centre for Scientific Research (CNRS, Centre National de la Recherche Scientifique) requesting that the most internationally cited researchers, according to the highly cited researchers $(\mathrm{HiCi})$ database ${ }^{24}$, should highlight their university affiliation in their first signature rather than that of the $\mathrm{CNRS}^{25}$ because account is only taken of the first signature in the Shanghai ranking ${ }^{26} \ldots$ a request that confirms the significance of this ranking and its prescriptive dimension.

Ministerial officials are not the only players to show interest in the ranking. The analysis of the profile of the players cited in the corpuses revealed other strategic uses of the ranking, illustrating that power relations are exercised through, and for, the discursive media and that the media coverage process is co-constructed over the medium term. The variety of profiles, particularly of academic 


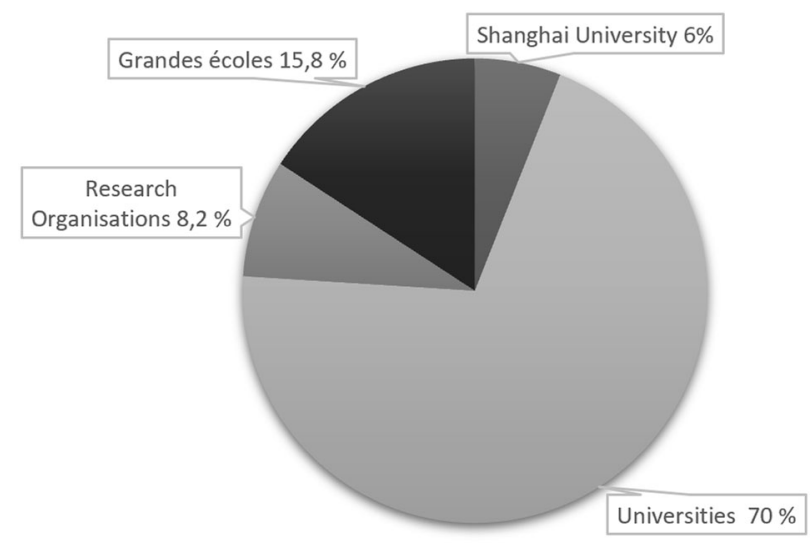

Fig. 4 Profile of academic enunciators. Distribution of affiliations of academic enunciators, Press Corpus 2003-2014.

players, highlights the hierarchies and power relations within the world of higher education \& research in France.

The analysis of the profile of the academic players who have discussed the ranking (examined by listing citations, interviews and published opinion pieces) shows the importance of their positioning and the challenges within the world of higher education \& research. The positions on the ranking thus reflect the historical specificities of the French education and research system, where universities, grandes écoles and research organisations $^{27}$ coexist and reveal internal hierarchies regarding the representation of academic prestige. Thus, there emerge power relations between the different institutions: between universities, between universities and grandes écoles, and between universities and public research organisations, as well as between scientific disciplines, such as physics, mathematics... (Fig. 4). It is chiefly university presidents, directors of grandes écoles or research bodies who react to the ranking. From the point of view of scientific disciplines, several studies have focused on the varying degrees of appropriation of quantitative assessment tools, depending on the disciplines and internal hierarchies of the French higher education \& research system (Pontille and Torny, 2010, 2012; Gozlan, 2016). The presidents of scientific universities (mathematics, physical sciences, biology, etc.) have taken advantage of the ranking to strengthen their communication and to counter their reputation deficit overshadowed, as they are, by the prestige of the grandes écoles. It also appears that the comments on the ranking have contributed to enhancing the role of the university presidents, revealing the plurality of rationales involved in the dynamics of the process.

Interviews with journalists highlighted the complexity-and, sometimes, the ambiguity-of interactions with university presidents or directors of higher education \& research institutions who, on the one hand, are contacted by journalists as sources of information and comments and who, on the other hand, themselves enter into contact with editorial staff or send press releases in response to the publication of the ranking, expecting their comments to be picked up and repeated ${ }^{28}$. If the ranking functions as a judgement tool, leading to a revision of the reputations of institutions, it will also provide an opportunity to strengthen positions poorly valued by society in the scale of French academic prestige, either in terms of the type of institution (grandes écoles versus universities) or the discipline (specialists in literature compared to physicists, mathematicians, biologists, etc.), as indicated by the significant proportion of enunciators who hold the position of university president, in particular specialist in sciences such as physics, mathematics... i.e., almost $45 \%$ of academic enunciators.

Interview Les Echos, 27 April 2011: 'The ranking was paradoxically useful to university presidents, all the universities in France had to have their own micro lab. But it was not a lab that was ranked but an entire university. It put the university presidents back in control of guiding research, a fact that explains the interest expressed by the university presidents'.

Universities that thought they were included in the ranking but were not-such as the University of Paris-Dauphine, which was not ranked in 2003 but would be in $2004^{29}$-would comply with the ranking criteria (Espeland and Sauder, 2007) by recruiting teaching/research staff, winners of Nobel Prizes or Fields medals, in order to be included in the ranking, attesting to the 'performativity dimension' of the ranking system.

Letter A, 13/07/2007: '[...] The Faculty of Paris-Dauphine has been included in the ranking of the 500 best universities in the world, drawn up every year by the University of Shanghai and which is now an authority in this area. This distinction is linked to the recruitment of two lecturers who have obtained the Fields Medal (the equivalent of the Nobel Prize for mathematics), including Pierre-Louis Lions, who is also a professor at the Collège de France.

As a judgement tool, the ranking reveals the tensions and hierarchies of the French higher education \& research system and goes hand-in-hand with different strategies that attest to the numerous uses it generates (argument for university mergers, as a communication tool, etc.).

Anita Bersellini, quoted in AEF, 12 July, 2004: 'Strategic alignment of the development policies of Paris-XI, ParisXII, Versailles-Saint-Quentin, Evry and the Cachan ENS (Ecole Normale Supérieure)

The universities of Paris-XI Sud, Paris-XII Val-de-Marne, Versailles-Saint-Quentin, Evry Val-d'Essonne and the Cachan ENS are considering 'a strategic alignment of their development policies'. (...) The 'trigger', says Anita Bersellini, was the publication of the ranking of the 500 best universities in the world by Shanghai Jiao-Tong University: Paris-VI was the first French university in the ranking in the 65th place, followed by Paris-XI, ranking 72nd (AEF dated 12 January, 2004). 'Legibility in research is necessary', she adds, also referring to the White Paper on an 'ecosystem for growth' (AEF dated 28/04/2004)'.

Le Monde, October 1st, 2008: 'Better to be ranked low than ignored

'2008 Shanghai ranking: Joseph-Fourier University, the sixth largest university in France, retains its place in the 'Top 200' world universities'. Starting on 15 August, the date when the ritual benchmark ranking of world universities is published, universities, like Grenoble-I, have become accustomed to immediately sending out their selfcongratulatory press releases. It's a matter of prestige. From Pierre-et-Marie-Curie (Paris-IV), first French university in the Shanghai ranking, to Rennes-I, 23rd and last representative (ranked between the 402nd and 503rd establishment) of the French delegation, all the establishments are delighted to be among the happy few. 'We entered the ranking in 2005. That was an important moment for us, showing a degree of recognition for our work,' says $\overline{\text { Albert }}$ 
Marouani, president of the University of Nice-Sophia Antipolis. When he arrived in 2004, the brand new vicechancellor announced his intention to quickly enter the 'Top 500'. (...) 'This ranking has the merit of existing and of not being based on 'auto-reporting', a fact that guarantees a minimum quality', says Anita Bersellini, President of the University Paris-Sud (Paris-XI), the second French university in this ranking. 'All the criteria are objective: the number of Nobel Prize winners, Fields medals winners, publications in Science \& Nature, researchers cited, etc. [...]. On the other hand, Alain Beretz asserts, 'In Strasbourg, I don't base my policy on the results of the rankings. I follow them, but as a general trend. Since the creation of the Shanghai ranking, we've been placed at about No. 100. Our ambition, above all, is to improve our quality, not to improve our position. That must come naturally. Moreover, if we followed that approach, we would never have agreed to create a single university. On he contrary, teaming up with a university teaching human and social sciences and a university specialising in law would make us lose places in the next ranking...'

The Shanghai ranking viewed as a judgement tool is used in the definition of the strategies devised by the establishments but it also functions as a communications tool, notably in the case of institutions included in the ranking, such as the University of Paris VI-Pierre et Marie Curie (UPMC).

The University of Paris VI is strongly represented among the academic bodies expressing themselves about the ranking with 39 occurrences (quotations, interviews, opinion pieces): 25 in the press corpus and 14 in the AEF corpus. The successive university presidents, Gilbert Béréziat ${ }^{30}$, Jean-Charles Pomerol ${ }^{31}$ and Jean Chambaz, ${ }^{32}$ were to communicate on the results from the very outset of the media coverage process, Paris VI being consistently the top-ranked French university, except in 2011 and 2012 (in 2011, Paris XI was 40th and Paris VI, 41st and in 2012, Paris XI was 37 th and Paris VI, 42nd).

In September 2004, after the publication of the second edition of the Shanghai ranking, the University of Paris VI purchased advertising space in two national daily newspapers to promote itself. This intention is clearly underlined in an article published by the weekly Nouvel Observateur on 16 September, 2004. While the emphasis is placed on the underperformance of French institutions and Gilbert Béréziat's comments advocating a merger between grandes écoles and universities, the reference to the ranking contributes to the revaluation of university education in the so-called hard sciences in the scale of academic prestige.

Article from the Nouvel Observateur, 16 September 2004: 'When Jussieu advertises itself-'Get involved... in science'

The famous Parisian university has decided to use advertising to get scientific studies out of the doldrums. [...] Paris-VI's advertising, of which the ads published in Le Monde and Libération represent just one phase, is also targeting an audience beyond French borders. And there's a lot to do. Because in the war waged by world universities to attract young brains, the university of Pierre-et-MarieCurie-Paris-VI still compares very badly. True, it's the first French university cited in the Shanghai ranking, but it only appears in the 41st place worldwide. Far behind the Americans and, in Europe, behind Oxford, Cambridge and the Swiss and Dutch polytechnics, as emphasised in the university's advertisement. The fault lies with May ' 68 , in particular, which irrevocably tarnished the prestigious name 'Sorbonne' when the university was divided up between several sites in Paris, while Harvard or Columbia kept theirs. If he is not working to rehabilitate this venerable name, Gilbert Béréziat has another idea to improve its visibility: 'It would be better to merge the grandes écoles with the universities'.

While the ranking is a communication tool, it is also a resource when you have access to media outlets to take up a position. Stigmatised by what had been presented as underachievement, the grandes écoles were to react, through their representatives, to the publication of the ranking results as early as 2004 . Individuals speaking on behalf of the grandes écoles represent $19 \%$ of the academic enunciators in the press corpus. Their prestige allows them to influence debates on higher education \& research and to put the 'bad result' into perspective. In terms of academic prestige, the grandes écoles in France stand at the very top of the scale (Bourdieu, 1984, p. 19).

From the beginning of the media coverage process, we observe a reaction on the part of the directors of the École des Mines, the École normale supérieure (ENS) and the INSA ${ }^{33}$ de Lyon, and it was from 2007 onwards, in a context of the political use of the ranking to justify the reforms in progress, that their voice became more present, with contributions from the directors of ENS-Ulm and ENS-Lyon, HEC, École centrale, Institut d'études politiques (IEP) de Paris (Sciences-Po), École polytechnique, and TelecomParis-Tech (ENST). One of the presidents of the Conférence des grandes écoles (CGE), the national institution set up to represent the schools of engineering and business administration, sought to relativise the criteria adopted by the ranking, without calling into question the axiological conformity of this judgement tool with the elitist model embodied in these schools.

Les Echos, 17/09/2007: 'The grandes écoles, which are not shy about adopting a rather paradoxical position, admit it quite clearly: these rankings, however useful they may be, must be handled with caution. 'They have an impact on students, and are a positive stimulus, but we must be vigilant about the criteria used,' warns Christian Margaria $^{34}$, President of the Conférence des grandes écoles.'

While the beginning of the process in 2004 was marked by the publication of opinion pieces by members of the higher education \& research community, these publications intensified in 2007 and 2008 , bearing witness to the intensity of the debates. The corpus of opinion pieces revealed that $85 \%$ of the profiles of the commentators dealing with the ranking come from the academic world (university presidents, researchers or research directors, directors or lecturers from the grandes écoles). This corpus has made it possible to observe the importance of interactions and power relations played out between stakeholders, notably members of the academic community who entered into a proxy debate, with the signatories of opinion pieces using their respective articles to reply to one other.

The place of the grandes écoles in the scale of academic prestige can be assessed by the number of their representatives who publish opinion pieces (Fig. 5), i.e., slightly $<17 \%$, because the 'opinion piece' genre requires specific resources justifying the publication of a well-argued point of view. Regardless of the diversity of the grandes écoles and the profiles of the commentators, their positioning in the hierarchies within higher education \& research helped to make their voices heard in the debates on higher education \& research, notably during the 2007 presidential campaign. This is reflected in the comments of the Director of HEC in two opinion pieces, published in 2006 and 2007, which set out to highlight the lack of resources for public-funded research.

Opinion piece by Bernard Ramanantsoa, CEO of the HEC group, Le Figaro, 5 March, 2007: 'Research and education at the heart of the campaign 


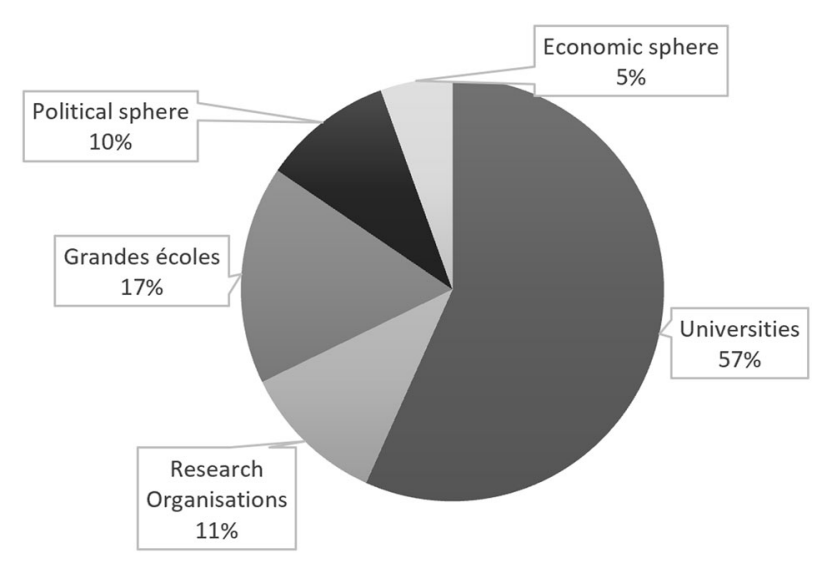

Fig. 5 Profiles of the enunciators of opinion pieces. Distribution in \% of the profiles of the enunciators (corpus of opinion pieces).

For once, everyone seems to agree. In a campaign characterised by contrasting positions, one issue wins unanimous support: research and higher education have a key role to play in the country's future. Let us not indulge in alarmism: the Shanghai ranking is not everything and some of our institutions are doing well in global competition. But for how long, if we do not quickly realise the magnitude of the efforts to be made? Harvard University alone has reserves of 22 billion euros. France's public research budget is barely 11 billion euros.....

The content of the 90 opinion pieces that address the ranking highlights a salient discursive feature of the corpora, namely the frequent use of a concessive mode as in statements of the type 'decried, certainly, but unavoidable', 'questionable yet authoritative'. This concessive mode is an argumentative construction that combines an argumentative movement in two steps. The first argument is followed by a second, which restricts or refutes the first. contributing to the neutralisation of counter-arguments and the acceptance of this judgement tool as something natural.

The analysis of the methods of disseminating the Shanghai ranking shows that the acute importance of reforms in higher education \& research and the multiplication of arguments about academic 'excellence' provided a favourable environment for the media coverage of the Shanghai ranking, which also provided a journalistic resource for creating a buzz', increasing the attention of the media, as well as that of political or academic players. The analysis highlights the strategic uses made by the different stakeholders contributing to the dissemination of this ranking and its co-construction as an archetype of the academic ranking. If the derogatory framing in the 'buzz-creation' process applied to the ranking favoured its media coverage, the importance of the use of the concessive mode helped to neutralise counter-arguments and to make this judgement tool accepted as something natural (Barats 2019). Over the period studied, the ranking functions as an argument justifying reforms for politicians and as a communication tool for certain academic players. The co-construction of the media coverage process, notably by political and academic players, helps to shape the ranking as a judgement tool and as a means for producing value, which contributes to reconfiguring the prestige and reputation of the entities ranked: the ranking becomes a communication tool or, conversely, a tool of stigmatisation based on a name and shame approach.

The interest given to this ranking has strengthened and amplified the media coverage process by the reactions generated by the creation of the 'buzz', driven by a circular dynamic that feeds itself: the media coverage of the Shanghai ranking contributes to its reputation, its reputation helps to enhance the status of this ranking, which amplifies its legitimacy and, in turn, its media coverage. We also demonstrated that the plasticity of rankings, the simplicity of Academic Ranking of World Universities's criteria, the periodicity of its publication (lack of news during the summer period), as well as the characteristics of the French system of higher education \& research are important factors for the dissemination of this ranking.

In this way, the media coverage of the Shanghai ranking as a judgement tool has become a factor in the power relations in France between stakeholders in higher education \& research and has helped to call into question the way-chiefly qualitative-in which academic excellence is appraised, i.e., located and anchored in the endogenous norms of the university profession (MignotGérard and Sarfati, 2015; Gozlan, 2016) in favour of quantified indicators that would claim a certain universality, notwithstanding the diverse ways in which these judgement tools are appropriated. If national specificities can explain the dissemination of the ranking, our research confirms the importance taken at a European level of these judgement tools (Hazelkorn, 2007) and the prominence of competition (Musselin, 2017) and a market logic in policy making.

\section{Data availability}

The data sets generated and analysed during the current study are not publicly available due to press copyright but are available from the corresponding author on reasonable request. In the case of interviews conducted, they are also available from the corresponding author on reasonable request.

Received: 15 July 2019; Accepted: 10 March 2020;

Published online: 01 May 2020

\section{Notes}

1 Fields medallists were first included in 2004.

2 Ying Cheng, December 2010, source: https://www.slideshare.net/URAP/arwu.

3 In other countries, such as Germany, Belgium and Switzerland, a large number of commentaries also attest to the interest expressed in this ranking by the media, the world of academia and politics.

4 Only two press releases dated 6 November, 2012 and 4 August, 2017 appear on the university's website announcing, respectively, the first place obtained by the Biomedical Engineering Department and that of the Economics Department in the global ranking per academic subjects published since 2007 by ARWU (Academic Ranking of World Universities) in addition to the university ranking. Sources (accessed in May 2019): http://economics.harvard.edu/news/harvard-economicsranked-1-2012 andhttps://www.seas.harvard.edu/news/2017/08/harvard-first-inbiomedical-engineering-in-new-ranking-of-world-universities.

5 The agency was created in 1998. One-thousand seven-hundred organisations have taken out subscriptions, representing $\sim 15,000$ subscribers/readers. Since 2009, AEF has been offering its subscribers a permanent file devoted to academic rankings, an indication of the scale of the dissemination of these league tables and their success. Indeed, the articles devoted to rankings were among the most widely read publications. Source AEF: interviews in March 2011 and June 2015.

6 This complementary corpus has not been the subject of a systematic textual statistic analysis, unlike the first one. It has been subject to a qualitative analysis that confirms the trends observed.

7 Ten interviews were conducted with the journalists who chiefly covered the rankings (AEF, Le Monde, Les Echos, La Tribune, Le Figaro, Libération) from March 2010 to September 2015.

8 A French daily newspaper specialising in economic and financial news, similar to $L a$ Tribune

9 The work involved in documenting the body of publications has also revealed that the ranking was known in other areas of academic discourse production. For example, reference was made to the ranking in seminars organised by members of the higher education community, as well as in reports drawn up as early as 2004 .

10 The journalist was responsible for higher education at an international level and had just recently been recruited by AEF. 
11 Act No. 2007-1199 dated 10 August 2007.

12 http://textopol.u-pec.fr/textobserver/

13 https://www.image-zafar.com/Logiciel.html

14 The original French articles read as follows: Les Echos, 15/11/2004: «La France à la traîne dans le nouveau classement mondialL'université Jiao Tong de Shanghai vient de

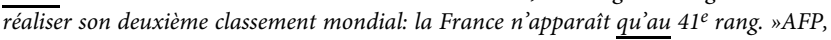
29/09/2005: " [...] Le très redouté 'classement de Shanghai' attribue chaque année un très mauvais score à la France: la première université française est classée en 2005 à la 46e place ".Les Echos, 01/04/2006: "Que valent encore nos universités?[...] Pauvres, surpeuplés, fragmentés, les campus français font en effet pâle figure sur la scène internationale: la première université n'apparaît qu'à la $46^{e}$ place du désormais célèbre "classement de Shanghai » et la première grande école... à la $93^{e}$. Ce classement, conçu par une université (Jiao Tong) jusqu'ici inconnue de la planète académique et pourtant aujourd'hui érigé en norme internationale, a fait l'effet d'un choc. Ce qui en dit long sur la déconfiture française ».Le Figaro, 27/02/2008: "Universités: un classement mondial pointe le retard françaisEnseignement supérieur: Le classement des universités par disciplines de Shanghaï relègue les établissements français à une médiocre place. Scruté à la loupe par les universitaires du monde entier, le cru 2008 du fameux classement des facs de l'université Jiao Tong de Shanghaï vient de sortir par grandes

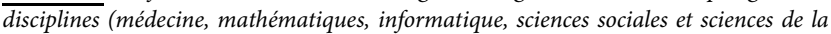
Terre). [...] Le palmarès 2008 est aussi médiocre que celui de l'an dernier: on note tout au plus qu'une université française intègre le Top 100 des facs de médecine ».Le Monde, 03/05/2012: " [...] Lorsque, dès 2003, le "Shanghaï choc " a ébranlé les certitudes de l'enseignement supérieur français, la droite a considéré qu'il fallait regarder ce qui marchait ailleurs et s'en inspirer pour éviter le déclassement ".Les Echos, 26/08/2013: "Le message de ShanghaiL'épreuve est quelque peu humiliante, mais on s'y est habitué. Comme chaque année depuis 2003, le classement mondial des universités, dit "classement de Shanghai", confirme le rang médiocre de la France: seulement 20 de nos établissements d'enseignement supérieur figurent parmi les 500 premiers - ce qui nous place bien après les Etats-Unis, la Chine, l'Allemagne ou le Royaume-Uni - et 4 parmi les 100 premiers. Nos milieux universitaires se rassurent en contestant la méthode d'évaluation, et leurs arguments sont recevables, mais ils passent à côté de l'essentiel ».

15 The definition of a typology to identify the profiles of enunciators making statements on this matter proved to be complex. The typology of the profiles was established iteratively by identifying the surnames and status as they appeared in the publication. More than $90 \%$ of the enunciators of the press corpus are political or academic players: political players are representatives of the regulatory authority, the executive power, and rarely of trade union organisations or parliament (32\% of the enunciators of the press corpus and $34 \%$ of the AEF corpus); academic players represent a diversity of teaching and research institutions, i.e., including universities, grandes écoles and research bodies (62\% of the enunciators of the press corpus and $55 \%$ of the AEF).

16 In France, the 'grandes écoles' are higher education \& research institutions with a specific status that recruit their students through competitive exams. They enjoy considerable prestige in France and were created in the 18th century such as, for example, the Ecole des Mines (1783) and the Ecole Polytechnique (1794), in order to train technical and military managers at the service of the State.

17 The CNRS (Centre National de la Recherche Scientifique, or National Centre for Scientific Research) was created in 1939 and reorganised after the war. It enjoys considerable prestige at national and international level.

18 Many CNRS researchers publish with university researchers but ARWU's criteria exclude CNRS publications.

19 Letter of appointment addressed to V. Pécresse, Minister of Higher Education \& Research, by F. Fillon and N. Sarkozy, Paris, 5 July, 2007.

20 This ranking, called U-Multirank, is presented in a mapping format. It was the subject of a call for tenders from the European Commission in December 2008 and was published online in May 2014.

21 In 2010, the French government set up a special investment programme entitled Programme d'investissement d'avenir, PIA ('Investment Programme for the Future'). From this funding programme, a total of 22 billion euros was earmarked for higher education \& research, of which 7 billion euros for the 'excellence initiative projects'.

22 Xavier Pons demonstrated that Luc Chatel, Minister of National Education, had contributed to the politicisation of the OECD's PISA ranking system in 2011 (Pons, 2015 , p. 200)

23 La prise en compte des classements internationaux dans les politiques de site ('The inclusion of international ranking in site policies'), IGEN/IGAENR Joint Report, No. 36, May 2017. This report presents the ranking methodologies, including the Shanghai ranking, and made about ten recommendations on the role played by the Ministry, the university mergers, expectations for benchmarking, etc.

24 https://hcr.clarivate.com/

25 Les Echos, Pourquoi la France va remonter dans le classement de Shanghai ('Why France will rise in the Shanghai ranking'), 28 February, 2019, p. 2.

26 This is linked to a change in methodology in 2014 that led the producers of the ranking to give a weighting to the influence of the new database, see http://www. shanghairanking.com/fr/ARWU-Methodology-2014.html (accessed May 2019) for further details.
27 Research organisations are public research establishments, such as the CNRS (Centre National de la Recherche Scientifique, or National Centre for Scientific Research).

28 This was one of the points highlighted in interviews with the journalists who wrote the articles.

29 It was ranked 385th in the 2004 edition and 334th in the 2018 edition.

30 Professor of biochemistry and molecular biology, university president of Paris VI (UPMC) from 2001 to 2006 (source: educpros.fr biography).

31 Professor of computer science and artificial intelligence, university president of Paris VI (UPMC) from 2006 to 2011 (source: educpros.fr biography).

32 Professor of cell biology, university president of Paris VI (UPMC) from 2006 to 2011 (source: educpros.fr biography).

33 National Institute of Applied Sciences, Engineering School

34 Mathematician, engineer at ENST, director of INT (Institut National des Télécommunications from 1995 to 2009), president of the Conférence des grandes écoles (CGE) from 2003 to 2009.

\section{References}

Barats C (2018) Comment le classement vint de Shanghai? In: Barats Bouchard, Haakenstad (eds) Faire et dire l'évaluation, L'enseignement supérieur et la recherche conquis par la performance. Presses des Mines, Paris, pp. 261-282

Barats C (2019) Á propos de la médiatisation du classement de Shanghai: l'apport de l'analyse du discours. Revue Française de Linguistique Appliquée XXIV (1):21-35

Billaut J-C, Bouyssou D, Vincke P (2010) Faut-il croire le classement de Shangaï? Revue de la régulation $8(2)$, [online]. http://regulation.revues.org/9016

Bourdieu P (1984) Homo academicus. Editions de Minuit, Paris

Brankovic J, Ringel L, Werron T (2018) How rankings produce competition. The case of global university rankings, Forthcoming in Zeitschrift für Soziologie, August 2018, [online] https://www.academia.edu/36893224/How_rankings_ produce_competition

Champagne P (1991) La construction médiatique des "malaises sociaux". Actes de la Recherche en Sciences Sociales 90:64-76

Champagne P (2000) L'événement comme enjeu. Réseaux 18(100):403-426

Charroin J (2015) Le classement de Shanghai, levier de la diplomatie d'influence chinoise? Revue internationale et stratégique 97:48-60

Docampo D (2013) Reproducibility of the Shanghai academic ranking of world universities results. Scientometrics 94(2):567-587

Docampo D, Egret D, Cram L (2015) The effect of University Mergers on the Shanghai Ranking. Scientometrics 104:175-191

Éloire F (2010) Le classement de Shanghai. Histoire, analyse et critique. L'Homme et la Société $178: 17-38$

Espeland W, Sauder M (2007) Rankings and reactivity: how public measures recreate social worlds. American Journal of Sociology 1(113):1-40

Espeland W (2015) Rankled by rankings: how media rankings redefined higher education. In: Bouchard \& al (éds), La médiatisation de l'évaluation-Evaluation in the Media, Peter Lang, pp. 25-37

Foucault M (1971) L'ordre du discours. Gallimard, Paris

Fridenson P (2010) La politique universitaire depuis 1968. Le Mouvement Social 233:47-67

Goffman E (1991) Les cadres de l'expérience (Frame analysis, an essay on the organization of experience, 1974). Éditions de Minuit, Paris

Goody J (1979) La raison graphique. La domestication de la pensée sauvage (The domestication of the savage mind, 1977), Éditions de Minuit, Paris

Gozlan C (2016) Les sciences humaines et sociales face aux standards d'évaluation de la qualité académique. Sociologie 7(3):261

Hazelkorn E (2007) L'impact du classement des établissements sur la prise de décision dans l'enseignement supérieur. Politiques et Gestion de l'enseignement Supérieur 19:95-122

Hazelkorn E (2014) The effects of rankings on student choices and institutional selection. In: Jongbloed B, Vossensteyn H (eds) Access and expansion postmassification: opportunities and barriers to further growth in higher education participation. Routledge, London

Hazelkorn E (2015) Rankings and the reshaping of higher education. the battle for world-class excellence, 2nd edn. Palgrave Macmillan, New York

Hazelkorn E (2011) Rankings and the reshaping of higher education: the battle for world-class excellence. Palgrave Macmillan

Liu NC, Cheng Y (2005) Academic ranking of world universities-methodologies and problems. Higher Education in Europe 30(2):127-136

Miège B (2010) L'espace public contemporain. Presses Universitaires de Grenoble, Grenoble

Mignot-Gerard S, Sarfati F (2015) Dispositif de jugement sur la qualité, ou instrument de construction de la réputation? Le cas d'un classement universitaire. Terrains et Travaux 26:167-195

Musselin C (2009) Les réformes des universités en Europe: des orientations comparables, mais des déclinaisons nationales. Revue du MAUSS 33:69-91

Musselin C (2017) La Grande course des universités. Presses de Sciences-Po, Paris

Pierru F (2004) La fabrique des palmarès. Genèse d'un secteur d'action publique et renouvellement d'un genre journalistique-Le cas du palmarès des hôpitaux. 
In: Legavre J-B (eds) La presse écrite: objets délaissés. L’Harmattan, coll. "Logiques politiques", Paris, pp. 247-270

Pons X (2015) "La médiatisation de PISA en France: travail journalistique et action publique", in Bouchard J et al. (eds), La médiatisation de l'évaluation, Evaluation in the media. Peter Lang, pp. 193-214

Pontille D, Torny D (2012) Rendre publique l'évaluation des SHS: les controverses sur les listes de revues de l'AERES. Quaderni 77:11-24

Pontille D and Torny D (2010) Revues qui comptent, revues qu'on compte: produire des classements en économie et gestion. Revue de la régulation 8/ Autumn. http://regulation.revues.org/8881

Ravinet P (2011) La coordination européenne "à la bolognaise". Réflexions sur l'instrumentation de l'espace européen d'enseignement supérieur. Revue française de Science Politique 61:23-49

Soulas T (2016) Thèse de doctorat en sociologie: "Business schools Made in China. L'émergence des écoles de gestion chinoises". November 2016, Université de Paris-Est

Vught F, Westerheijden Don F (2010) Multidimensional ranking: a new transparency tool for higher education and research. Higher Education Management and Policy 22:16

Werron T, Ringel L (2017) Rankings: conceptual remarks. geschlossene gesellschaften verhandlungen des 38 kongresses der deutschen gesellschaft für soziologie, edited by S. Lessenich, [online]. https://www.academia.edu/ 35056243/Rankings_Conceptual_remarks

\section{Acknowledgements}

I want to thank the Céditec and Mr. Malcom Scott for the translation.

\section{Competing interests}

The author declares no competing interests.

\section{Additional information}

Correspondence and requests for materials should be addressed to C.B.

Reprints and permission information is available at http://www.nature.com/reprints

Publisher's note Springer Nature remains neutral with regard to jurisdictional claims in published maps and institutional affiliations.

\begin{abstract}
(c) (i) Open Access This article is licensed under a Creative Commons Attribution 4.0 International License, which permits use, sharing, adaptation, distribution and reproduction in any medium or format, as long as you give appropriate credit to the original author(s) and the source, provide a link to the Creative Commons license, and indicate if changes were made. The images or other third party material in this article are included in the article's Creative Commons license, unless indicated otherwise in a credit line to the material. If material is not included in the article's Creative Commons license and your intended use is not permitted by statutory regulation or exceeds the permitted use, you will need to obtain permission directly from the copyright holder. To view a copy of this license, visit http://creativecommons.org/ licenses/by/4.0/.
\end{abstract}

(C) The Author(s) 2020 